\title{
Logic Model of Governance Innovation and Public Policy in Public Service
}

\author{
Lesmana Rian Andhika ${ }^{1}$ \\ Heru Nurasa ${ }^{2}$ \\ Nina Karlina ${ }^{3}$ \\ Candradewini Candradewini ${ }^{4}$
}

\begin{abstract}
This research aims to provide additional qualitative evidence of the logical relationship between governance innovation and public policy in public services in Indonesia with adopting the logic model. The logic model is often not adopting in the formulation of policies that resulted in the implementation of public sector innovation such as cannot show more significant results. Also this model is believed to contribute in planning and evaluation of government programs. Most of this article based on the literature study and direct observation. The study also refers to some cases were chosen deliberately and treated as evidence by using a descriptive qualitative approach for developing an argument and conceptual framework accordingly. This research resulted in some information. First, governance innovation will provide multi-benefits, not only for the government but will involve a range of other institutions. Second, public policy is treated as a formal legal basis to keep programs planning and evaluation. That way this article is expected to contribute to the knowledge development of logical relationships among governance innovation and public policy in the different local contexts Indonesia from countries which often becomes a reference in managing public service innovation.
\end{abstract}

\section{Keywords:}

governance innovation; public policy; public service

\section{Introduction}

Administrative reform appeared due to the severity of problems in public administration activities (Farazman, 2002). The term is intended to increase to case attention, and consequences of social change mainly through the bureaucracy. Reform efforts often understood as political motives to mobilize policies as a consequence of national independence, the anti-corruption movement, elite political consolidation, market economy expansion, employment, extraction, and foreign interests accommodation (Farazman, 2002). On the other hand, reforms are also the practice of power operating in a discursive process through truth claims on a particular reform model (Paskarina, 2017).

The reforms carried out in almost all forms of government activity and often

\footnotetext{
${ }^{1}$ Corresponding Author, Department of Administration Sciences, Faculty of Social and Political Sciences Universitas Padjadjaran

Email: lesmana15001@mail.unpad.ac.id

${ }^{2}$ Department of Administration Sciences, Faculty of Social and Political Sciences Universitas Padjadjaran

${ }^{3}$ Department of Administration Sciences, Faculty of Social and Political Sciences Universitas Padjadjaran

${ }^{4}$ Department of Administration Sciences, Faculty of Social and Political Sciences Universitas Padjadjaran
} 
associated with innovation (Kim \& Han, 2014; IGI, 2016; and see also Caiden, 2009). The classical innovation theory starts by thinking "Schumpeterian" which assumes a critical dimension of innovation as an economic change to develop new products and processes that result in high economic value (Sengupta, 2014). Views about the innovation definition are widely available in some literature, Baregheh, Rowley, and Sambrook, (2009) identify 60 definitions, innovation has become a universal definition adopted by many disciplines of knowledge. Innovation definition is the discovery of new ideas, ways, services, processes that are considered to include all scientific, technological, organizational, financial and commercial or intended to do innovation (Baregheh, Rowley, \& Sambrook, 2009; Wisdom et al., 2014; Agger \& Sorensen, 2016).

Further, government innovation requires a set of policies as a guide (Anttiroiko, Bailey, \& Valkama, 2011; Vries, Bekkers, \& Tummers, 2015). The researchers has highlighted some earlier studies that indicate linkages with innovation and policy. Siddiquee (2008) found that innovations and reforms introduced in general produce a positive impact but are limited. Therefore, he suggested the proposed policy implications should help the formulation of strategies and measures to further enhance the public service delivery and governance innovation of the public service. From the side of economic policy, innovation can expand the flow of foreign investment capital in a country, also implicates against state revenue (Fagerberg, 2017). However, the term view that policy can be instrumental in supporting the innovation has been widespread and commonly used (Edler \& Fagerberg, 2017).

The other side, innovation also needs to be well managed for such innovations can show the benefits. Scupola and Zanfei (2016) in his investigation revealed that governance innovation requires user participation to achieve greater inclusiveness. Although the governance theory rare in the innovation literature (Moore \& Hartley, 2008), the researchers can learn to governance innovation from concept and approach of innovation and governance contextually (Anttiroiko, Bailey, \& Valkama, 2011). Further, some of the existing concepts reveal that innovation governance at least deals with elements of policy-makers, managers, citizens (Hartley, 2005), democratic, managerial, development, and service function of government (Anttiroiko, Bailey, \& Valkama, 2011).

Primary goals of this research are to provide additional qualitative evidence of the logical relationship between governance innovation and public policy in public service. Surely this article cannot be a present relation between governance innovation and public policy throughout the public service. However, the researchers chose one of the many public services in the civil and registration record of local government. The reason is, population data are significant to use on the map of poor population, public services, development planning, budget allocation, development of democracy, and the rule of law. Also aims for self-identification and as a material to policy formulate strategic.

Although some studies have previously given a basic understanding of relationship governance innovation and public policy, our focus will be to reconstruct the logical framework arguments through the logic model. Also, this study provides evidence that obtained through the analysis and synthesis of scientific literature. Therefore, the researchers will be reviewing the logic model; the goal is to articulate and clarify the general principles of reasoning about knowledge for the claim and explain the implications and consequences inferential of relationship governance innovation and public policy. On the other hand, this article will discuss the primary research question that is until to what extent 
logical relationship governance innovation and public policy in civil registration records of local government? The rest of this article will discuss the theories framework, research methods, research results, and analysis.

\section{Methods}

This study adopted a qualitative descriptive method to answer the main of research question that has suggested before. The reason behind that, qualitative methods can be sustained by the fact so can explore and critically analyze some phenomena that surround research objects (Creswell, 2013). Also, the researchers use the approach that is driven by theory, using some theories to maintain investigation and analysis of the topics presented.

Then the researchers critically review and analyze relevant scientific books, journal articles, government regulations to develop a conceptual framework that fit and analyze some of the previous studies. The logic model is also used to articulate and clarify the general principles of logical reasoning about a relationship between governance innovation and public policy. This study tries to develop an appropriate argument, also refers to some cases chosen intentionally and treated as evidence. The data collected is then analyzed and interpreted using triangulation analysis to conclude with caution (Creswell, 2013; Nassaji, 2015). The last step is presenting a clear interpretation through discussions to describe a phenomenon and its characteristics.

\section{Results and Discussion}

The evolution of governance and innovation demonstrated the existence of a transition from the new public management. That approach illustrates the distribution of knowledge and innovation at different levels of organization in public administration (Bovaird \& Löffler, 2009). In practice, improvements in a radical and incremental change in government activity varied from large-scale national reforms to organizational innovation. Governance innovation related to how innovation managed with innovatively, and how an organization is moving from an idea to product or service. Understanding and managing innovation are one issue most widely in the contemporary public administration (Osborne \& Brown, 2011; Torfing \& Triantafillou, 2016). Thus, governance innovation seems very different from innovations in products, services, and processes (Moore \& Hartley, 2008; Anttiroiko, Bailey, \& Valkama, 2011; Scupola \& Zanfei, 2016). Governance innovation can promote innovation capacity from the public sector, arguing that it is often viewed as an alternative but should view as complementary.

From several existing theories the researchers decided to use governance innovation theory developed by Anttiroiko, Bailey, and Valkama (2011). They mention at least governance innovation related to democratic, managerial, development, and service function of government. The reason, governance innovation will provide the consequences of any such failure or success in innovation implementation (Moore \& Hartley, 2008; Scupola \& Zanfei, 2016). At the same time, there is certain timeliness for any debate on governance innovation and public policy. Leaders need to recognize the continuing relevance of traditions and themes of innovation responsibility for the public interest, integrity, honesty, and empathy (Moore \& Hartley, 2008; Bovaird \& Löffler, 2009; Anttiroiko, Bailey, \& Valkama, 2011; Scupola \& Zanfei, 2016). Then the researchers also established one of the many public policy theories developed by Dunn (2016). Dunn (2016) provides information that public policy is a political activity process. The process describes a series of interdependent stages between setting agenda, policy formulation, policy adoption, policy implementation, and policy evaluation. The reason is that the bureaucracy 
often becomes political exploitation, and also implement political decisions (Hill, 2005; Dunn, 2016).

The researchers will provide a relationship attribute from governance innovation and public policy theory through a logic model to get the logical realities that exist. The researchers recognize that these theories may revise, but the researchers give the assumption that policy will give an urge to the administrator to implementing of political decisions through government activities including innovation initiation. Further, the policy can also be a law that makes certain limitations to what should be done and not.

\section{Logic Governance Innovation and Public Policy}

First, the researchers will understand the logic model, how knowledge focuses on the logic, system and epistemic features from what is called context. Logicians wrote from 1948 to 1950's (Rudolf Carnap, Jerzy Los, Arthur Prior, Nicholas Rescher, GH von Wright) and others acknowledge that the discourse about knowledge and beliefs demonstrated systematic preferential treatment that recognizes feature deductive axiomatic (Gochet \& Gribomont, 2006; Hendricks \& Symons, 2006). Most systems of logic begin with the assumption that resembles the intuitive observation to plan and evaluate the program effectiveness (Knowlton \& Phillips, 2013).

Additional assumptions that serve as the basis for majority's logic includes the recognition that knowledge implies truth. Therefore, the researchers strive to do observations are evaluative, normative, and critical theory linking governance innovation and public policy. This effort was made rationally to determine our cognitive experience by reading literature studies, as well as observing the innovation, governance and policy activities of some local governments. It comes from official government portal information, regulations, and direct observation.

\section{Governance Innovation and Public Policy}

As have already explained, this study uses the theories of Anttiroiko, Bailey, and Valkama (2011) and Dunn (2016) to show the reality of their logical relationship. Therefore, illustrate the theory in Table 1.

\section{a. Democratic versus Agenda Setting}

Democratic in view Anttiroiko, Bailey, and Valkama (2011) refers to the political process mechanism to the policies production. Contemporary policy issues are the policy agenda as a separate political process element (Mortensen, 2010). For that agenda setting is an early stage of policy process (Dunn, 2016), even some practitioners agree that the initial problem identification will offer solutions to process further towards policy options that allow a problem can be solved with policies (Hill, 2005; Liu et al., 2010; Dunn, 2016; Baekgaard, Mortensen, \& Seeberg, 2018).

Therefore, the researchers can ask how much the resulting local policies to support

Table 1.

Logical Relationship Governance Innovation and Public Policy

\begin{tabular}{lll}
\hline \multicolumn{1}{c}{$\begin{array}{c}\text { Governance Innovation } \\
\text { Anttiroiko, Bailey, and Valkama (2011) }\end{array}$} & \multicolumn{1}{c}{$\begin{array}{c}\text { Public Policy } \\
\text { Dunn (2016) }\end{array}$} & \multicolumn{1}{c}{ Logical Relationship } \\
\hline Democratic & Agenda Setting & Policymaking process bounded rationality \\
Managerial & Policy Formulation & Public choice \\
Development & Policy Adoption & Policy diffusion \\
Service Function of Government & Policy Implementation & $\begin{array}{l}\text { Public service, discretion } \\
\text { Public trust (benefit of innovation; quality } \\
\end{array}$ \\
& Policy Evaluation & \\
& & of public service) \\
\hline
\end{tabular}

Sources: Elaborate by authors, based on Anttiroiko, Bailey, and Valkama (2011) E Dunn (2016) 
of innovation? Logically each government activity should be based on policy. Further, the researchers will show a recent study claiming that critical agenda are setting for the policy process. Pump (2011) explained that the agenda-setting must be holistic to consider the roles and relationships between legislative, bureaucracy, and interest's groups. Some parts of policy change can move at different speeds, probably caused by the complex problems in favor of regime's authorities. Study Baekgaard, Mortensen, and Seeberg (2018) show that the bureaucracy so far ignored in the determination of policy agenda. The professional administrators not given the opportunity to respond; even the bureaucracy is only considered to carry out every political decision.

Zahariadis (2016) argue why is the study of setting policy priorities important, first, studying the agenda as a list of priorities helps us understand social values. Second, specifying the agenda illuminates potential gaps between government and the public in democratic and non-democratic societies alike. Third, by their very existence priorities create political winners and losers. Fourth, agenda setting profoundly affects policy decisions. Fifth, agenda setting imbues meaning and importance to individuals and institutions beyond any that is formally assigned by constitutional or other legal rules. Therefore, we argue that the agenda setting is not only described as the ability to influence the importance of the topic public policy agenda, but "justice" sees contemporary issues into consideration. So the policy will determine every program of government activity.

\section{b. Managerial versus Policy Formulation}

As discussed earlier, government administrators not given the opportunity to provide feedback on contemporary issues in policy formulation. Policy formulation is an integral part of the planning process. Therefore, the managers (administrators) need to the right policies formulate. The researchers see that there are several key considerations in policy formulation: first, participation, in the context of modern government, citizen participation is often thought of as a represents of democracy (Michels \& Graaf, 2010; Michels, 2012). Second, organization goals, the policy is the outline and basic plan for the public service implementation, leadership, and how the way to act (primarily about governance, organization). Some arguments say, one of the government's goals is to provide excellent public services (Osborne \& Brown, 2011; Cooper \& Reinagel, 2015; Denhardt \& Denhardt, 2015). Third, consistency, policies that violate higher rules must be eliminated (Craft \& Howlett, 2012). As a consequence, the result is inconsistent between policies that cannot be adopted appropriately. Therefore, it is essential to ensure that all policies are linked to organizational goals and should not provide guidelines contrary to higher rules. Fourth, network and coalitions, the critical consequence of policy design is the extent to which executives devise policies that can determine the direction of the government programs. On the other hand, the legislature does not quickly approve, therefore conducive conditions between the pro government's and opposition must be well preserved (Gerston, 2010).

For example, some models of good government and governance indicating public participation is very important. However, that in policy formulation, it is often impressed that it only obeys the rules, and only involves specific communities that do not represent the citizen. Worse yet the involvement of academics are often not included and can give the assumption that an independent team of academics would be providing input that is critical to policy formulation. Therefore, most likely to respond to the policy formulation is the government administrators (Koski \& Lee, 2014; Romance, 2015).

Further DuBrin (2006) dividing the managerial criterion of a leader be a technical 
skill, interpersonal skills, conceptual skills, diagnostic skills, and political skill. How far that ability is will reflect the manager (administrators) capacity to be able to manage the organization with all the consequences that arise. The concept of knowledge management teaches a series of strategies, techniques, and systems used to manage the knowledge (Saulais \& Ermine, 2012). The researchers admit that measuring the administrators capacity not only measured the knowledge they have. However, more important is the desire to give changes radically in planning and implementation activities.

\section{c. Development versus Policy Adoption}

Development technologies platform web 2.0, 3.0, and to date has reached 4.0, aims to improve the interaction effect between government and public (Khan, 2017). The used for transformation and technology also lies in its logical value and benefits. However, the available literature reveals a mixed view of technology effects uncertainty and customer engagement at this stage of the new service development process (Hameed, Counsell, \& Swift, 2012; Navarro, 2016). Many innovations that can implement, but that innovation idea is like left to not developed, in the absence of a limited set of rules, budgets, and human resources. The researchers see much innovation in different local governments, but the innovation does not show more significant results. For example, innovation in the sector of civil registration record, in some areas has done various development of population administration services to achieve the recording targets.

As Klungkung Regency, motorcycle, and car use, to deliver services that reach out to remote areas and crowded (Dukcapil Kabupaten Klungkung, 2017). DKI Jakarta government with innovations Si Dukun (Integrated System of Population Document Three Institutions) (Dirjen Dukcapil, 2018).
Some of the innovation literature available reveals that innovation is not always presented using high technology, but ideas/ways that are considered new or developing existing ones also include innovation (Sorensen \& Torfing, 2011; Torfing \& Triantafillou, 2016). Therefore, it is essential to provide research facilities to develop the innovation for the better. If local governments do not have research facilities, they can cooperate with educational institutions.

Further, local governments often adopt the way other as a reference but not adopt in the form of policy. The consideration is that when the government will decide to adopt a similar policy and have succeeded in a different place, the policymaker will generally think of relative benefit received (Eseonu \& Wyrick, 2014; Gilardi, 2016). Policy diffusion is not just the adoption of similar policies from other successful states/regions, but policy diffusion is a continuous learning process (AutantBernard, Fadairo, \& Massard, 2013; Maggetti \& Gilardi, 2015; Gilardi, 2016). His goal was to find to effective and quality policy that does not contradict with higher regulation by adopting a way from elsewhere by considering the characteristics and culture of a particular area.

\section{d. Service Function of Government versus Policy Implementation}

Service function of government at this time more open, accessible, and responsive. For this utility to work functions, the government must find ways and improve public services. On the same side, the user is positioned only as a recipient because of public services have been regulated. The user does not have the option to select of quality, the quantity of service itself. Therefore, very innovations contribute to public service quality. Only innovation will give options to the user in different ways and will shape the perception of users that innovation is one way the government presents the public service. 
In any complicated situation, policymaking and policy implementation are interrelated phenomena and influence each other. Often, the policy must be changed and revised because it takes into account the experience gained. Also, the policies are often subject to various interpretation (Keeler, 2013; Howe, 2014; McHarg, 2017). In such cases, the administrator is responsible for policy implementation, can use their discretion in policy interpret. Apart from that, it seems that bureaucracy plays a dominant role in policy making because of the political system under development, on the contrary for the bureaucracy in the modern state is very dependent on the bureaucracy for policy formulation and policy implementation. On the other hand, there are often interest groups affecting the policy implementation. Interest groups will pursue their interests by using tactics on the weak links of the bureaucratic chain to influence process implementation.

\section{e. Policy Evaluation}

Evaluation needs a fresh look at the idea of policy evaluation and its intimate, dynamic connection with evaluation practice. Policy evaluation has always been a topic of concern in the field (Trochim, 2009). Policy evaluation is an activity where develop an understanding of principles and evaluation methods to check content, implementation or policy impact. For example, the policy of recording data and electronic-based documents aimed at the integration of data nationally. Electronics use only for the printing of the document, and data collection on electronic makes it possible to shorten the registration time. However, the way this has to be balanced with a variety of innovations to speed up the process of data registration. Although electronic-based, still many people have not been registered and have documents. The results of observation, we found in Aceh Tenggara Regency, January 2017 there 21,058 not yet to register of population data (Dukcapil Kabupaten Aceh Tenggara Report, 2017) that exceeds the amount of population growth each year as many as 4,000 (BPS, 2017). The cause is the service of discriminatory and still occurrence of illegal charges (pungutan liar).

Recent studies have also that revealed bad policy product could affect people's lives (Aghion et al., 2010; Bovens \& Hart, 2016). That means existing policy can not necessarily be considered successful in its implementation. Therefore Trochim (2009) confirms the importance of policy evaluation. First, the evaluation policy is valuable for its signaling role. Second, evaluation policies help make evaluation a more transparent and democratic that particular endeavor. Third, the evaluation policy is also a mechanism for broader learning about evaluation. Fourth, the evaluation policy is potentially an efficient mechanism for changing practice. Finally, the evaluation policy is essential because many of the controversies in the evaluation are mostly about such a policy.

If the policy is aim nobly, it would greatly help government administrators to perform their functions. However many policies often aimed at legalizing the interests of a particular group. The policy would be dangerous if starting from the formulation with the not procedurally. Ministry of Home Affairs Republic of Indonesia report there is a mention about 3,143 rules canceled, 1,765 local regulation/regulation of regional head which revised, 111 regulation of the Minister of Home Affairs revised, and 1,267 local regulation/regulation of regional head revised by the governor (Kemendagri, 2016). Such circumstances given logic models give a sign that the process of policy formulation is not done with logical thinking, and not paying attention to the implications that this may cause. 


\section{Implication Governance Innovation in Civil Registration Record}

Innovations typology as radical and incremental innovation is innovation ty pology refers to the improvement of products, services, and processes which has existed (Sen \& Ghandforoush, 2011). Therefore, to increase innovation to show more significant results then it needs to be managed innovatively. The researchers have highlighted some governance innovation from local governments in managing innovation on the civil registration records, illustrated in Table 2.

Unlike developed countries which consider innovation an objective necessity (Anttiroiko, Bailey, \& Valkama, 2011; Agger \& Sorensen, 2016; Torfing \& Triantafillou, 2016), but in Indonesian need more efforts to maximize the governance innovation on the civil registration records. In this time innovation is often required in government activities, it is not difficult to find innovations in government activities. That when practitioners and experts create different categories of innovation often starts with innovation categories of products, services, and technology (Moore \& Hartley, 2008).

The researchers noticed that implications of governance innovation in civil registration records tend to the direction of collaboration, participation, and cooperation with the private sector. For example, in general, innovation movements in an area are often initiated by local leaders through a movement of change. Then the movement is implementing by institutions in the form of collaboration, participation with other institutions. On the other hand, the cooperation with the private sector for information dissemination through electronic media distribution did so that information can access by the public. However, participation, collaboration, and cooperation with the private sector often have constraints caused by policies that do not exist. The researchers see Padang Pariaman Regency implement governance innovation with a wide range of policy first, then followed by a variety of innovatively such as direct visits and the use of cars. Our logical assumption is that the implications of governance innovation are innovation will show more significant results when innovation manage innovatively with policy support, collaboration, participation, and cooperation with the private sector.

\section{Logic Model Governance Innovation and Public Policy}

The researchers have discussed the logical relationship between governance innovation and public policy; and will then show the logic model and explain the role of governance innovation and public policy. In organizations such as governments, requires the design, planning, monitoring, and evaluation of each

Table 2.

Civil registration record innovation in local government

\begin{tabular}{lll}
\hline \multicolumn{1}{c}{ Local government } & \multicolumn{1}{c}{ Civil registration record innovation } & \multicolumn{1}{c}{ Core public service } \\
\hline DKI Jakarta City & Si Dukun 3 in 1 & $\begin{array}{l}\text { Collaboration with the hospital, newborn, } \\
\text { automatically gets essential public } \\
\text { services such as a family card, residency } \\
\text { registration number, a social security card. }\end{array}$ \\
Batang Hari Regency & $\begin{array}{l}\text { Village head election (PILKADES) through } \\
\text { voting electronic system which uses e-ID Card, } \\
\text { a unique number of the family registration, and } \\
\text { child born certificate }\end{array}$ & $\begin{array}{l}\text { Mobile service } \\
\text { Tanah Datar Regency eltronic election }\end{array}$ \\
Surakarta City & $\begin{array}{l}\text { Online Anywhere Service } \\
\text { Record in the school program }\end{array}$ & The target for 17-year-old \\
\hline
\end{tabular}

Source: Regulation Minister of Administrative and Bureaucratic Reform No. 20/2017 (Determination Top 99 Public Service Innovations of 2017) 
program. The element of these functions as the basis for problem-solving. Therefore, the evidence-based model is a great help in any context. The logic model was characterized initially by planning and program evaluation as a tool for identifying performance measures (Williams, 2014). Logic models are a graphic way to organize information and display thinking. Logic models are tools that convey a scheme, program, or project in a brief, visual format, and logic models describe the planned action and its expected results (Knowlton \& Phillips, 2013). Firstly, will visualization the program logic model in Figure 1.

This program model shows the desired results including managing innovation with innovative ways; it implies producing agenda public service desired. If resolved then contribute to improve the quality of public service. To "read" these models Knowlton and Phillips (2013) gives a clue. First look at the desired impact or goal of the program that is "public service." Then move to the left side, where resources or inputs to the program is register. Logic model using the sequence "ifthen" between of the elements. When applied to elements in each column then the sentence is "If we have the resources, then we can provide this activity.", "If we pursue this activity, then we can generate this output.", "If we have this output, then we will develop these results," and so on. The researchers recognize that logic models are just one of many models of how a program might be designed and planned for implementation. Figure. 1 is, in fact, a program with certain of lack. Therefore, Knowlton and Phillips (2013) remind us always discussions when a program wants to design and how the program could

Figure 1.
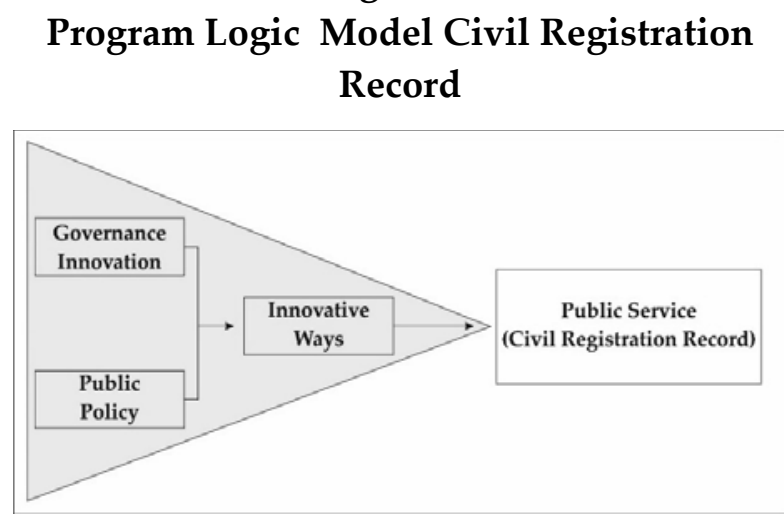

Source: Modify by Authors, Based on Knowlton and Phillips (2013)

Figure 2.

\section{Evaluation Logic Model Civil Registration Record}

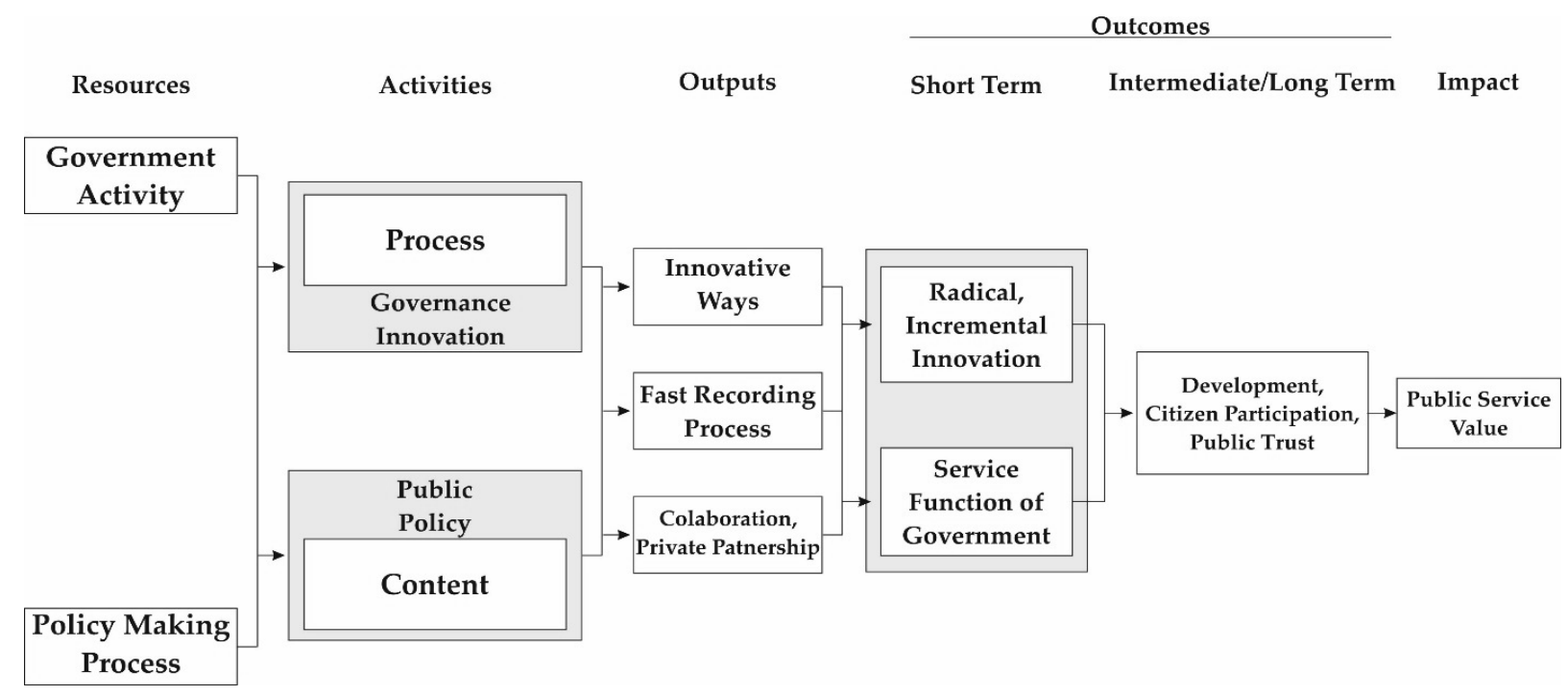

Source: Modify by Authors, Based on Knowlton and Phillips (2013) 
improve through a "mark up" (or critical review) that test the program design.

In the program evaluation phase, the logic model overcomes the problem because they illustrate the concepts to consider when looking for the program results itself. The logic model includes the specified resources/inputs, activities, outputs, outcomes, and impacts. Further, the model will help to identify a vital partnership to improve performance. For the evaluation phase we to visualize in a Figure. 2.

Resources or input is what is needed to ensure the program can operate. The activity is a tactical action (e.g., innovation, policies, publication) which happens to any strategy implement. The output is the descriptive indicator of specific activities that result. The result is a change in knowledge, skills or behaviors; its effects reflect changes in a shorter period. From the logic model, the researchers understand that a program in government activities should be designed by involving practitioners as a broad contributor of knowledge. The weakness of local government is rarely using the practitioners' knowledge give to respond. Moreover, governance innovation in any sector is not just a concept, but implementation becomes more critical to show innovation can innovatively provide more significant results.

\section{Implementation of the Logic Model}

The government of Indonesia Regulation $38 / 2017$ about local government innovation is the legal basis for innovation implementation. For example, about governance innovation, the policy does not explain in explicit the way for local governments to manage. Therefore, need to derivate the local level policies for governance innovation in a manner that designed before. As figures 1 and 2 provide information on how the logic model can be instrumental to demonstrate impact and goal of innovation. Then the logic model also represents the flow of activities, processes, results, and output. Knowlton and Phillips (2013) provide a more detailed explanation that the logic model is the process of designing a program (innovation) through various instruments such as policies. The policy will set about mechanisms, goals, and results involving a variety of related elements. In the case of governance innovation, practitioners and academics give the interconnectedness of some elements in the governance innovation.

For example, the involvement of the private sector with partnerships model (Alberti \& Bertucci, 2007), a collaboration model between government institutions (Anttiroiko, Bailey, \& Valkama, 2011; Agger \& Sorensen, 2016), the involvement of educational institutions as joint research efforts (Torfing \& Triantafillou, 2016). On the other hand, community participation as recipients and users of innovation influences governance innovation (Hartley, 2005; Anttiroiko, Bailey, \& Valkama, 2011; Sorensen \& Torfing, 2011). If the involvement of some of these elements did not explicitly explain in the policy, then sometimes the previous program designed just impressed the obligations of the power regime area (Anttiroiko, Bailey, \& Valkama, 2011; Denhardt \& Denhardt, 2015). The researchers also noted that "logic model" does not guarantee that this model would be very logical to understand. The current references mention many logical models that can be adopted logically that present possibility, feasibility, and success (Knowlton \& Phillips, 2013; Williams, 2014). The researchers believe that the most significant logic model value is its iterative use, a deliberate process aimed at improving thinking. At least understanding shows that governance innovation and public policy relationship will provide a better level of management effectiveness by presenting the logic model first in agenda setting and policy formulation.

\section{Conclusion}

Governance innovation was a problematic act when innovation implemented, and many innovations cannot show more significant 
results. Specifically, for civil registration records sector, innovation will increase the population data recording. Innovation with appropriate governance innovation will provide multieffect, not only for government needs but will involve other institutions. Further, citizen participation as users can contribute to the development of the innovation further. The policy should support any government activity. When the policy can not explicitly explain its intent and purpose, administrators may use discretion to policy interpretation. Policy choice also played an essential role in the adoption and assimilation of existing policy. The crucial role of innovation with all the possibilities that exist in government activity is to present good public services.

The researchers are aware of this article might be fraught with limitations due to incomplete information. However, at least this article can complement previous studies which also discusses relationships governance innovation and public policy. Therefore, suggest to researchers of the future study to be able to reconstruct this article in empirical research again. Finally, the researchers can give recommendations to the government administrator to perform a logic model in advance when planning and evaluation of a program. His goal was to see the possibilities of various implications caused the program itself before a policy will enact.

\section{References}

Agger, A., \& Sorensen, E. (2016). Managing collaborative innovation in public bureaucracies. Planning Theory, 1-21. doi:10.1177/1473095216672500

Aghion, P., Algan, Y., Cahuc, P., \& Shleifer, A. (2010). Regulation and distrust. The Quarterly Journal of Economics, 125(3), 10151049. doi:10.3386/w14648

Alberti, A., \& Bertucci, G. (2007). Innovation in governance and public administration: key issues and perspectives. In Department of
Economic and Social Affairs, Innovations in Governance in the Middle East, North Africa, and Western Balkans: Making Governments Work Better in the Mediterranean Region (pp. 3-12). New York: United Nations.

Anttiroiko, A.-V., Bailey, S. J., \& Valkama, P. (2011). Innovations in public governance in the western world. Amsterdam: IOS Press BV.

Autant-Bernard, C., Fadairo, M., \& Massard, N. (2013). Knowledge diffusion and innovation policies within the European Regions: challenges based on recent emperical evidence. Research Policy, 42(1), 196-210. doi:10.1016/j.respol.2012.07.009

Baekgaard, M., Mortensen, P. M., \& Seeberg, H. B. (2018). The bureaucracy and the policy agenda. Journal of Public Administration Research and Theory, 28(2), 239-253. doi:10.1093/jopart/mux045

Baregheh, A., Rowley, J., \& Sambrook, S. (2009). Towards a multidisciplinary definition of innovation. Management Decision, 47(8), 1323-1339. doi:10.1108/00251740910984578

Bovaird, T., \& Löffler, E. (2009). Public management and governance (2nd ed.). New York, NY: Routledge.

Bovens, M., \& Hart, P. (2016). Revisiting the study of policy failures. Journal of European Public Policy, 23(5), 653-666. doi:10.1080/13 501763.2015.1127273

BPS. (2017). Kabupaten Aceh Tenggara dalam angka 2016. Banda Aceh: Al-Mufadar.

Caiden, G. E. (2009). Administrative reform. Chicago: Aldine Transaction.

Cooper, C. A., \& Reinagel, T. P. (2015). The limits of public service motivation: confidence in government institutions among public servant. Administration \& Society, 89(9), 1297-1317. doi:10.1177/0095399715581039

Craft, J., \& Howlett, M. (2012). Policy formulation, governance shifts and policy influence: location and content in policy advisory systems. Journal of Public Policy, 32(2), 79-98. doi:10.1017/ S0143814X12000049 
Creswell, J. W. (2013). Qualitative inquiry $\mathcal{E}$ research design: choosing among five approaches (3th ed.). Thousand Oaks, CA: SAGE Publications.

Denhardt, J. V., \& Denhardt, R. B. (2015). The new public service revisited. Public Administration Review, 75(5), 664-672. doi:10.1111/puar.12347

Disdukcapil Kabupaten Aceh Tenggara Report. (2017). Laporan data perekaman penduduk Kabupaten Aceh Tenggara tahun 2017. Kutacane: Dinas Kependudukan dan Pencatatan Sipil Kabupaten Aceh Tenggara.

Disdukcapil Kabupaten Klungkung. (2017, March 10). Predator berkeliaran urus E-KTP masyarakat Klungkung. Retrieved from https://www.disdukcapil.klungkungkab. go.id/baca-artikel/27/Predator-BerkeliaranUrus-EKTP-Masyarakat-Klungkung.html

Disdukcapil Kabupaten Padang Pariaman. (2017, December 29). Raih zona hijau, Disdukcapil Padang Pariaman terus tingkatkan kualitas pelayanan. Retrieved from http:// dukcapil.padangpariamankab.go.id/index. php?option $=$ com_content $\&$ view $=$ article $\&$ id=187:zonahijau\&catid=88:berita\&Item $\mathrm{id}=2327$

Dirjen Dukcapil. (2018, February 2). Luncurkan Si Dukun, DKI layani 6 in 1 dokumen kependudukan. Retrieved from http:// www.dukcapil.kemendagri.go.id/detail/ luncurkan-si-dukun-dki-layani-6-in-1dokumen-kependudukan-3

DuBrin, A. J. (2006). Essential of management (9th ed.). Mason, $\mathrm{OH}$ : Cengage Learning.

Dunn, W. N. (2016). Public policy analysis (5th ed.). Oxon: Routledge.

Edler, J., \& Fagerberg, J. (2017). Innovation policy: what, why, and how. Oxford Review of Economic Policy, 33(1), 2-23. doi:10.1093/ oxrep/grx001

Eseonu, C. I., \& Wyrick, D. A. (2014). A heat transfer model for policy diffusion. Engineering Management Journal, 26(2), 3948. doi:10.1080/10429247.2014.11432009
Fagerberg, J. (2017). Innovation policy: rationales, lessons, and challenges. Journal of Economic Surveys, 31(2), 497-512. doi:10.1111/joes.12164

Farazman, A. (2002). Administrative reform in developing nations. Westport: Praeger Publishers.

Gerston, L. N. (2010). Public policy making process and principles (3rd ed.). New York: M.E. Sharpe.

Gilardi, F. (2016). Four ways we can improve policy diffusion research. State Politics \& Policy Quarterly, 16(1), 8-21. doi:10.1177/1532440015608761

Gochet, P., \& Gribomont, P. (2006). Epistemic logic. In D. M. Gabbay, \& J. Woods, Handbook of the history of Logic (pp. 99-195). Netherlands: Elsevier B.V.

Hameed, M. A., Counsell, S., \& Swift, S. (2012). A conceptual model for the process of IT innovation adoption in organizations. Journal of Engineering and Technology Management, 29, 358-390. doi:10.1016/j. jengtecman.2012.03.007

Hartley, J. (2005). Innovation in governance and public services: past and present. Public Money \& Management, 25(1), 27-34. doi:10.1111/j.1467-9302.2005.00447.x

Hendricks, V., \& Symons, J. (2006, January 4). Epistemic logic. Retrieved from https://plato. stanford.edu/entries/logic-epistemic/

Hill, M. (2005). The public policy process (4th ed.). Essex: Pearson Education.

Howe, L. E. (2014). Administrative law and governmentality: politics and Discretion in a changing state of sovereignty. Administrative Theory E Praxis, 24(1), 55-80. doi:10.1080/10 841806.2002 .11029340

IGI Global Disseminator of Knowledge. (2016, October 24). What is administrative reform. Retrieved from http://www.igi-global.com/ dictionary/administrative-reform/681

Keeler, R. L. (2013). Managing outsourced administrative discretion. State and Local Government Review, 45(3), 183-188. doi:10.1177/0160323X13496108 
Kemendagri. (2016, June 21). Unggah 3.143 Perda, Mendagriberterimakasih ke semua pihak. Retrieved from http://www.kemendagri. go.id/news/2016/06/21/unggah-3143-perdamendagri-berterimakasih-ke-semua-pihak

Khan, G. F. (2017). Social media for government: a practical guide to understanding, implementing, and managing social media tools in the public sphere. Singapore: Springer Nature.

Kim, S., \& Han, C. (2014). Administrative reform in South Korea: new public management and the bureaucracy. International Review of Administrative Science, 0(0), 1-19. doi:10.1177/0020852314558034

Knowlton, L. W., \& Phillips, C. C. (2013). The logic model guidebook: better strategies for great results. Thousand Oaks: SAGE Publications.

Koski, C., \& Lee, T. (2014). Policy by doing: formulation and adoption of policy through government leadership. The Policy Studies Journal, 42(1), 30-54. doi:10.1111/ psj.12041

Liu, X., Vedlitz, A., Lindquist, E., \& Vincent, K. (2010). Understanding local policymaking: policy elites' perceptions of local agenda setting and alternative policy selection. The Policy Studies Journal, 38(1), 69-91. doi:10.1111/j.1541-0072.2009.00345.x

Maggetti, M., \& Gilardi, F. (2015). Problems (and solutions) in the measurement of policy diffusion mechanisms. Journal of Public Policy, 00(0), 1-21. doi:10.1017/ S0143814X1400035X

McHarg, A. (2017). Administrative discretion, administrative rule-making, and judicial review. Current Legal Problems, 70(1), 267303. doi:10.1093/clp/cux011

Michels, A. (2012). Citizen participation in local policy making: design and democracy. International Journal of Public Administration, 33(4), 285-292. doi:10.1080/01900692.2012.6 61301

Michels, A., \& Graaf, L. D. (2010). Examining citizen participation: local participatory policy making and democracy. Local
Government Studies, 36(4), 477-491. doi:10. 1080/03003930.2010.494101

Moore, M., \& Hartley, J. (2008). Innovations in governance. Public Management Review, 10(1), 3-20. doi:10.1080/14719030701763161

Mortensen, P. B. (2010). Political attention and public policy: a study of how agenda setting matters. Scandinavian Political Studies, 33(4), 256-380. doi:10.1111/j.14679477.2010.00254.x

Nassaji, H. (2015). Qualitative and descriptive research: data type versus data analysis. Language Teaching Research, 19(2), 129-132. doi:10.1177/1362168815572747

Navarro, F. M. (2016). From government innovation to public innovation. International Journal of New Technology and Research (IJNTR), 2(6), 4-7.

Osborne, S. P., \& Brown, L. (2011). Innovation, public policy and public service delivering in the UK: the word that would be king?. Public Administration, 89(4), 1335-1350. doi:10.1111/j.1467-9299.2011.01932.x

Paskarina, C. (2017). The making of competitive bureaucracy: a case of bureaucratic reform in west java province. Cogent Social Sciences, 3(1), 1-13. doi:10.1080/23311886.2016.127 3748

Pump, B. (2011). Beyond metaphors: new research on agendas in the policy process. The Policy Studies Journal, 39(1), 1-12. doi:10.1111/j.1541-0072.2010.00389_1.x

Roman, A. V. (2015). The determinants of public administrators' participation in policy formulation. American Review of Public Administration, 47(1), 102-129. doi:10.1177/0275074015577799

Saulais, P., \& Ermine, J.-L. (2012). Creativity and knowledge management. The Journal of Information and Knowledge Management Systems, 42(3/4), 416-438. doi:10.1108/03055721211267521

Scupola, A., \& Zanfei, A. (2016). Governance and innovation in public sector services: the case of the digital library. Government 
Information Quarterly, 33(2), 237-249. doi:10.1016/j.giq.2016.04.005

Sen, T. K., \& Ghandforoush, P. (2011). Radical and incremental innovation preferences in information technology: an empirical study in an emerging economy. Journal of Technology Management $\mathcal{E}$ Innovation, 6(4), 33-44.

Sengupta, J. (2014). Theory of innovation: a new paradigm of growth. Switzerland: Springer International Publishing .

Siddiquee, N. A. (2008). Service delivery innovations and governance: the Malaysian experience. Transforming Government: People, Process and Policy, 2(3), 194-213. doi:10.1108/17506160810902194

Sorensen, E., \& Torfing, J. (2011). Enhancing collaborative innovation in the public sector. Administration \& Society, 43(8), 842868. doi:10.1177/0095399711418768

Torfing, J., \& Triantafillou, P. (2016). Enhancing public innovation by transforming public governance. Cambridge: Cambridge University Press.

Trochim, W. M. (2009). Evaluation policy and evaluation practice. In W. M. Trochim,
Evaluation policy and evaluation practice: new direction for evaluation 123 (pp. 13-32). San Fransisco: Jossey-Bass.

Vries, H. d., Bekkers, V., \& Tummers, L. (2015). Innovation in the public sector: a systematics review and future research agenda. Public Administration, 94(1), 146166. doi:10.1111/padm.12209

Williams, D. (2014). The evolution of the performance model from black box to the logic model through systems thinking. International Journal of Public Administration, 37(13), 932-944. doi:10.1080/01900692.2014. 944989

Wisdom, J. P., Chor K. H. B., Hoagwood, K. E., \& Horwitz, S. M. (2014). Innovation adoption: A review of theories and constructs. Adm Policy Ment Health, 41(4), 480-502. doi:10.1007/s10488-013-0486-4

Zahariadis, N. (2016). Setting the agenda on agenda setting: definitions, concepts, and controversies. In N. Zahariadis, Handbook of Public Policy Agenda Setting (pp. 1-24). Cheltenham: Edward Elgar Publishing. 